Алесь Макарэвіч

Магілёусккі дзяржайны ўніверсітэт

\title{
Эстэтычная праблематыка грамадзянскага, творчага, асабовага зместу ў лірыцы Вацлава Ластоўскага
}

Паэтычная спадчына В. Ластоўскага адносна невялікая: пачаўшы пісаць вершы амаль у саракагадовым узросце, ён стварыў ix каля чатырох дзясяткай. Тым не меней, у лірыцы гэтага паэта выразна прасочваецца своеасаблівая паэтычная канцэпцыя адносна такіх эстэтычных праблем, як ідэал грамадзяніна сваёй краіны, змагара за яе цяперашняе і будучае шчаслівае жыццё, змест літаратурнага твоpa, эстэтычная пазіцыя творцы i інш. Пры гэтым важна адзначыць наступнае. Эстэтычная канцэпцыя В. Ластоўскага, адлюстраваная у яго лірычных творах, гэта - сукупнасць поглядаў, перакананняй, доказаў, якія у у кожным наступным (паводле часу стварэння) вершы уддакладняюцца, пашыраюцца, ствараючы у выніку аб’ёмны сэнс у адносінах да адпаведных праблемы ці з'явы. Такая канцэпцыя мае свае вытокі ў творчасці гэтага пісьменніка: літаратурна-крытычныя артыкулы, апавяданні, навуковая, грамадская дзейнасць і інш.

Аналізуючы лірыку В. Ластоўскага $\ddot{\mathrm{y}}$ кантэксце прапанаванай тэмы ${ }^{1}$, возьмем пад увагу наступную тэзу. Цэнтральнымі аб'ектамі па асновах і спосабах уключэння ў эстэтычныя адносіны у разглядаемых ніжэй вершах В. Ластоўскага з'яўляюцца: 1) г р а м а д с к я я ў чы н к і, якія ацэньваюцца не толькі па іх эфектыўнасці, а і у суадносінах з эстэтычным ідэалам; 2) грамадзянская пазіцыя суайчыннікаў і яе вынікі ӱ рэстраспектыве, рэальным і будучым жыцці; 3) п ак а з чык і

1 Ніжэй прадстайлена характарыстыка найбольш паказальных, на наш погляд, вершаў у адносінах да вызначанай у назве артыкула праблематыкі. 
духо уннага свету асобнага чалавека як: а) прадмет яго (чалавека) самавыражэння; б) частка іншага духоўнага свету (людзі, ix узаемаадносіны, мастацкая прастора і яе рэцэпцыя і інш.), на які гэты чалавек можа ўплываць; 4) м а с т ац к і я т в о р ы, што маюць адпаведную сілу эстэтычнага ўздзеяння, якое з'яўляецца вынікам папярэдняй дзейнасці іх стваральнікай.

Звернемся да характарыстыкі вызначаных вышэй аб'ектаў у лірыцы В. Ластойскага. "Наперад, змагарна наперад!..” (1922). Гэты верш адносіцца да таго перыяду, калі В. Ластойскі ўзначальваў эміграцыйны ўрад БНР.

У чым дасягнуй відавочных поспехаў эміграцыйны ўрад БНР - пра Беларусь загаварылі ў Еўропе. А сам Власт у гэтыя гады звярнуўся да... паэзіi. У ёй працягваў сцвярджаць ідэю змагання за незалежную Беларусь. Такая вось новая, мо і не дужа яркая, грань таленту былога сакратара «Нашай нівы». Ластоўскі-паэт дэбютаваў на пачатку 1922-га, у першым нумары часопіса «Беларускі сцяг» [вершам "Наперад, змагарна наперад. - A. M. $]^{2}$.

На падставе класіфікацыі мастацкіх вобразаў, прапанаванай М. Эпштэйнам (прадметная, абагульнена-сэнсавая $i$ структурная сферы $\left.^{3}\right)$, вызначым ідэйны змест верша "Наперад, змагарна наперад!..", беручы пад увагу, што матыў змагання за волю Бацькаўшчыны развіваецца і ўдакладняецца ў іншых лірычных творах В. Ластойскага.

У сувязі з адзначаным вышэй прапануем наступную гіпотэзу адносна грамадзянскай лірыкі В. Ластойскага: гэтая частка спадчыны пісьменніка ўтрымлівае ў сабе эстэтычную лірычную канцэпцыю патрыятычнага зместу, якая $\breve{y}$ сукупнасці з падобнай лірычнай сэнсаўтваральнай канцэпцыяй іншых пісьменнікаў (напрыклад, У. ЖКылкі) сведчыць пра адметны патрыятычны напрамак у беларускай лірыцы 1920-х гадой.

Прадметная сфера мастацкіх вобразаў верша "Наперад, змагарна наперад!.." прадстаўлена наступнымі двума слаямі: 1) слой вобразаў-дэталяй, 2) фабульны слой. Пры гэтым важна адзначыць, што вобразы-дэталі ў іх спалучэнні паміж сабой і ў сукупнасці з адпаведны-

2 Я. Янушкевіч, Вяртанне з нематы, [у:] В. Ластоўскі, Выбраныля творы, Мінск 1997, c. 12 .

3 Литературньй энциклопедический словарь, под общ. ред. В. М. Кожевникова, П. А. Николаева, Москва 1987, с. 253-254. 
мі тропамі (метафары, эпітэты і інш.) уключаюцца $\ddot{y}$ фабульны слой, спрыяючы гэтым самым пашырэнню яго сэнсу.

Слой вобразаў-дэталяў: * воля (аб'ект закліку); *nомста (суб'ектны выток змагання); *нахрапная крыйда (аб'ект адмаўлення); *вольньг ў кайданах прастор (аб'ект абароны); *думь горкія, сэрцьи нашы (вытокі змагання); *артоўны тапор - сякера (сродак змагання); *nраметна заборчасиь, *nадзельг; *i здзекі, i крыйды, $i$ пот, * Бярэсuе $i$ Рыга ${ }^{5}$ (сацыяльныя прычыны барацьбы), *наездиык - крыўдзі-

4 Маюцца на ўвазе вынікі Брэсцкага мірнага пагаднення 1918 года. Яны наступным чынам характарызуюцца сучаснымі гісторыкамі. Гэта мірны дагавор Сав[ецкай] Расіі з Германіяй, Аўстра-Венгрыяй, Балгарыяй $i$ Туриылй. Падпісаньи ў Брэст-Літоўску (Бярэсце) 3.3.1918, ратыфікавань 4-м Надзвычайныл Усерасійскім з'ездам Саветай 15.3.1918 і герм[анскім] імператарам Вільгельмам II 26.3.1918.

Б[рэсикі] м[ip] фармальна завяршьў перьяд удзелу Расіі ў першай сусветнай вайне 1914-18, з'явіусся вынікам няздольнасці Расіі прачягваць ваен[ныя] дзеянні. (...) Б[рэсикі] м[мір] стаў першым паражэннем курсу бальшавікой на падрыхтоўку сусв[етнай] рэвалюџыі і меў вынікам абвастрэнне ўнутрыпаліт[ычнай] барачьбы на аснове розных адносін да міру з боку розных паліт[ычных] пльняў у Расіі. (...) Бел[арускае] пытанне на перагаворах самастойнага значэння не набыло. Інтарэсы беларусаў не былі прыняты пад увагу ні адным з бакой. Паводле умой Б[рэсикага] [міру] тэр[ыторыя] Беларусі была падзелена па лініі Дзвінск - Свянцяны - Ліда Пружань - Бярэсие. Немцы арыентаваліся на стварэнне [малой Літвы] з далучэннем да этнічнай Літвы часткі бел[арускіх] зямель, у $m[$ вим] л[іку] Віленшчыны $і$ Гродзеншчыныл. Астатняя тэр[ыторья] Беларусі разглядалася як прэрэгатывва Расійскай Федэрачьі. (...) Беларусь не атрыллівала нічога на аднаўленне разбуранай у час вайны гаспадаркі, таму што Германія і Расія ўзаемна адмовіліся ад пагашэння страт, прычыненых вайной насельнічтву гэтых дзяржаў. Такія абразлівыя адносі-

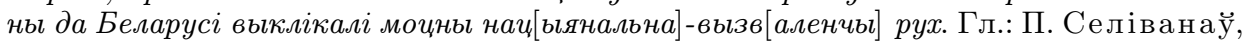
Брэсикі мір 1918, [у:] Энцыклапедыя гісторыи Беларусі: У 6 т., Мінск 1994, т. 2, c. $102-103$.

5 Маюцца на ўвазе вынікі Рыжскага мірнага пагаднення 1921-га года. Іх наступным чынам характарызуе гісторык У. Арлой: Рыжская мірная дамова была заключаная у 1921-м годзе паміж Савецкай Расіяй і Польшчай у выніку расійска-польскай вайньл. Беларуская дэлегаџыя таксама прыехала уั Рьгу, але яе проста не дапусиілі да перамоваў. Так адбылося таму, што значная частка польскіх палітькаў глядзела на Беларусь не як на дзяржаву, а як на свае “крэсы всходні" $i$ з гэтага сыходзілі. А Савечкая Расія проста гандлявала нашай тэрыторыяй у сваіх мэтах. Па уัмовах дамовы да Польшчь былі далучаныя 29 паветаў Беласточкага, Віленскага і Навагрудскага ваяводствау - тэрыторыля плошчай 113 тысяч квадратньх кіламетраў з насельнічтвам больш за 3,5 мільёна чалавек. У той жа час была зной абвешчаная БССР. Яе плошча на той момат была 52,4 тыс. кв. кіламетраў. Гэта крыху больш за чвэрџь сёнешняй тэрыторыі Беларусі. Тады нават нарадзілася прыказ$\kappa a$ - "У Беларусі тры сталічь - Менск, Лагойск і Плешчанічы". Гэта было амаль што так, таму што Віџебская, Магілёуская і Смаленская губерніі былі перададзеныля Расіі. Толькі потым частка гэтых земляу была вернутая Беларусі намаганнямі начьлянальна арыентаваных камуністаў. Варта сказачь, што расійскія бальшавікі прапаноўвалі па уัмовах дамовь перадаць Польшчь ўсю Беларусь. Палякі адмовіліся, таму што баяліся, што проста не здолеюць прадльнуць такі вялікі кавалак. Але гэта сведчьць аб тым, што для Масквы Беларусь была не больш чым аб'ектам 
чель-грабічель (аб’ект барацьбы); * пасока чорная - чорная сукравіца6 (прамежкавы вынік помсты).

Фабульны слой - гэта * уззаўленне народнага гневу (першая страфа); *вызначэнне яго вынніковасиі (другая, чацвёртая строфы); * канстатаџыя прычын народнай помсты (трэцяя страфа).

Такім чынам, "Наперад, змагарна наперад!.." В. Ластоўскага гэта своеасаблівы патрыятычны эпіграф (калі ўлічыць той факт, што дадзеным вершам пачыналася новая старонка ў творчасці паэта: стварэнне ім грамадзянскай лірыкі) да яго лірычных твораў са змагарнымі матывамі. У вершы "Наперад, змагарна наперад!.." аўтар агучвае ідэю грамадскай барацьбы супраць наездчыкай, крыўдзічеляў-грабічелей, якія пануюць у яго родным краі. Змагарная ідэя дадзенага твора - гэта ідэя незалежнасці Беларусі, яе права на самастойнае вырашэнне свайго цяперашняга (на момант стварэння верша) лёсу і вольнага выбару гістарычных перспектыў.

"Б л а г а с л а ў лён с ын..." (1922). Гэты верш можа ўспрымацца як заклік, адрасаваны сучаснікам В. Ластоўскага і будучым пакаленням беларусай.

У творы кожная новая яго частка ўзмацняе сэнс папярэдняй, а сукупнасць усіх частак спрыяе стварэнню аб'ёмнага грамадска-эстэтычнага сэнсу. 3 мэтай доказу гэтай тэзы вылучым і ахарактарызуем інтэрпрэтацыйныя часткі, іх вобразы і сэнс.

1. Благаслаўлён сын, // які за Маці чэсиь // гатоў да бітвы стаць нябарна $(\ldots)^{7}$.

Тут сэнсава вызначальным з'яўляецца вобраз сына, які гатоў абараняць Maці. У дадзеным выпадку можна правесці паралель са Свяшчэнным пісаннем: Шануй бацьку твайго і маці, каб падойжыліся дні твае на зямлі, якую Гасподзь, Бог твой, дае табе (Выхад 20: 12).

гандлю. Тым не менш, тэрыторыя Беларусі была так пасечаная, і мяжа з Польшчай была так блізка, што даходзіла да кур'ёзаў. Напрыклад, калі ў 30-х гадах у Менску быу пабудавань Оперны тэатр, нехта прапанаваў паставіџь на ім 60-мятровую статую Сталіна, але гэтая прапанова была не прынятая з той прычыныь, што такая статуя была б бачная з польскай тэрыторыі $і$ ў выпадку вайны была б выкарыстаная артылерыяй у якасиі арыенціра. Гл.: Для Беларусі Рыжская дамова - тое ж, што для Польшчы Пакт Молатава-Рьгбентропа. Гл.: [Электронны рэсурс]: Рэжым доступу: http://www.europeanbelarus.org/be/news/2009/9/17/764, Дата доступу: 10.09.2015.

6 СУКРОВИЦА ж. рэдкая часиь крывві, крывяное малако; па́сака. Гл.: В. Ластойскі, Падручны расійска-крыусскі (беларускі) слоўнік, Коўна 1924, с. 692.

7 В. Ластоўскі, Выбраныля творы, Мінск 1997, с. 206. У далейшым спасылкі на гэта выданне падаюцца ў тэксце з указаннем у дужках старонкі. 
У гэтай частцы верша В. Ластоўскі апасродкавана сцвярджае абавязак сына не толькі шанаваць сваіх бацькоў, а і аберагаць іх яшчэ і дзеля таго, каб працягнуць існаванне свайго роду. Такім чынам, п а-п е рш а е, аўтар характарызуе сына, які гатовы абараняць сваю маці, як чалавека благаслайлёнага: благаслаўлёнага Богам на дабро, на добры ўчынак, добрае жыццё. П а - д р у г о е, гэтым самым ствараецца эстэтычна ўзвышаны вобраз удзячнага сына.

2. Благаслаўлён сын, // які (...) // гатоў (...) // свабоды дзень для ўсіх // сваёи крьввёи // купіць ахвярна (206).

Вылучым у гэтай частцы два блокі і інтэрпрэтуем іх сэнс.

П а - п е рш ае, паводле сцверджання аўтара, благаславёным з'яўляецца змаганне за свабоду. У дадзеным выпадку падразумяваецца не толькі свабода маці, а і ўсіx: бацькой, іх дзяцей, сям'і сына, да вобраза якога ў дадзеным выпадку адсылае аўтар, і інш. Прыгадаем, што брат, сястра - гэта яшчэ і дзеці бацькой кожнага чалавека. Клопат пра ix - гэта найперш клопат пра дзяцей сваіх бацькоў, а значыць, - пра бацькой, пра іх спакой, пра іх сучаснае і будучае.

Па - др у г о е, В. Ластойскі звяртае ўвагу на ахвярную крой для дасягнення свабоды. У сувязі з гэтым можна правесці аналогію з новазапаветным біблейскім фактам самаахвярнага подзвігу (ахвярнай крыві) Ісуса Хрыста, які свядома пайшоў на прызначаныя яму Стваральнікам пакуты. Пралітая крой Ісуса Хрыста, акрамя іншага, сімвалізуе сабой ідэю духойнага ўзвышэння чалавецтва. На падставе адзначанага можна прыйсці да наступнага вываду. У вылучанай тут частцы верша гутарка ідзе пра благаславенне для сына-змагара на яго самаахвярнае змаганне за будучы дзень гарманічнай свабоды: царства свабоды. Як Айцец Усявышні благаславіӱ Хрыста на пакутную смерць для царства духойнай гармоніi, так і лірычны герой В. Ластойскага атрымлівае благаслаўленне на ахвярнае змаганне за царства свабоды для Маці-Радзімы.

3. Благаславён муж, каторы мсчіџь // знявагу праў грамадскіх // i слёзы ўдоў. // Благаславёньь будзь, каторь // адплату кройю дасць за крой // і ворага прымусіџь // імя Беларусі // чиіџь... (206).

У гэтай, як і ў наступнай (чацвёртай) інтэрпрэтацыйнай частцы, назіраем, на першы погляд, некаторую неадпаведнасць старазапаветным маральным сцверджанням пра неабходнасць міжасабовага прымірэння і любові да блізкага свайго.

Прыгадаем адпаведныя часткі з Бібліі: (...) не паўставай на жыџьчё блізкага твайго (...) Не варагуй з братам тваім (...) Ня помсьиі $і$ ня май намыслу на сыноў народу твайго, любі блізкага твайго, як самога 
сябе (...) (Лявіт 19: 16, 17, 18). Пры гэтым зазначым, што дадзены наказ скіраваны на ўмовы мірнага сацыяльнага суіснавання.

У той жа час, калі возьмем пад увагу той факт, што ў вершы гутарка ідзе пра абарону паніжаных, пакрыўджаных, тых, чыя крой была пралітая бязвінна, то адзначаная вышэй неадпаведнасць паэтычных сцверджанняй В. Ластоўскага біблейскім запаветам страчвае сваю актуальнасць. Пацвярджэнне гэтай выснове знаходзім у такіх частках Старога запавету, як Лявіт, Выхад.

Хто зробіць шкодзіну на целе блізкага свайго, таму трэба зрабіць тое самае, што ён зрабіў:

пералом за пералом, вока за вока, зуб за зуб; як ён зрабіў шкодзіну на целе чалавека, так і яму трэба зрабіць.

Хто заб'е быдла, павінен заплаціць за яго; а хто заб'е чалавека, таго трэба аддаць сьмерці (Лявіт 24: 19-21).

(...) а калі будзе шкода, дык аддай душу за душу, вока за вока, зуб за зуб, руку за руку, нагу за нагу, апёк за апёк, рану за рану, сіняк за сіняк (Выхад 24: 23-25).

Наказ … агучваецца таксама і $\ddot{y}$ Другім законе - (19: 21).

Абарона свайго, роднага ў хрысціянскай традыцыі лічыцца святой справай; шлях на такі грамадзянскі подзвіг благаслаўляўся свяшчэннаслужыцелямі.

У сувязі з гэтым звернемся да інтэрпрэтацыі прапанаванага айтарам сцверджання благаславёнасці помсты мужа. Муж у дадзеным кантэксце - гэта мужчына, спрадвечным абавязкам якога быў клопат пра дом, сям'ю, удоў і інш. У такіх абставінах помста выступае своеасаблівай формай абароны ад навалы; яна - святая справа. У цытаванай вышэй інтэрпрэтацыйнай частцы гутарка ідзе пра грамадcкiя npaвbl. Значыць, і тут на першы план таксама выходзіць эстэтычны змест: прыгожым з'яўляецца тое жыццё, якое скіраванае на здабыванне не толькі грамадскай свабоды (другая інтэрпрэтацыйная частка), а і грамадскай справядлівасці ((...) i ворага прьлмсічь // iмя Беларусі // чиіщь... (206)).

4. Хай прыйдзе ён [той, хто адплату кройю дасць за крой. - A.M.], як Бог, // адзет у помсть тучу: // пад громай гук, маланак блеск, // пад славы песнь пявучу! (206). Тут вызначаецца місія мсціўцаў за кроў Маці-Радзімы; яе дзеці з'яўляюцца зброяй помсты уे руках Бога. В. Ластоўскі жадае бачыць мсціўца адзетым у помсты туиу. Такім чынам, відаць, сцвярджаецца неабходнасць натхнення мсціўцаў на змаганне вялікай іх колькасцю (тучай) за вольную Айчыну. Вобразы громаў гук, маланак блеск падкрэсліваюць прыхільнасць, падт- 
рымку шырокай быційнай прасторай той помсты, неабходнасць якой сцвярджае аўтар. Змагар за вызваленне Радзімы ў дадзеным выпадку параўнойваецца з Богам. 3 аднаго боку, такі факт падкрэслівае богайгоднасць грамадскай noмсты: змагары за шчасце Радзімы зброя ў руках Стваральніка. 3 другога боку, аўтар жадае, каб прыход вызваліцеля-абаронцы быў прыняты на Радзіме як з'ява, вартая славы, каб ён прыйшоў пад славы песнь пявучу.

Такім чынам, верш В. Ластоўскага "Благаслаўлён сын..." - гэта твор грамадзянска-эстэтычнага зместу: у ім адбываецца мастацкая гутарка пра высокія (самаахвярныя) адносіны чалавека да сваёй Радзімы. Заклікі гэтага твора могуць праецыравацца і на нядаўняе мінулае ад стварэння верша, і на сучаснае аўтару жыццё, і на будучы час.

Можна меркаваць, што асэнсаванне В. Ластоўскім нацыянальна-грамадзянскай бяздзейнасці суайчыннікаў у мінулым і сучаснасці прывёў яго да паэтычных высной-абвінавачванняў, выказаных у 1924 годзе ӱжо у вершы "О, Крыўская зямля...". Верш жа "Бла-

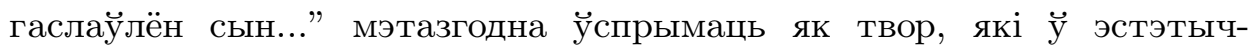
най канцэпцыі аўтара папярэднічае вершу "О, Крыўская зямля..." (верш-сцверджанне, які гучыць як трагічнае абвінавачванне папярэднікам і сучаснікам паэта). Тое існаванне, якое канстатуе В. Ластоўскі у вершы "Благаслаўлён сын...", - вынік, акрамя іншага, пазбаўленасці крыйцоў Божага благаславення на цяперашняе добрае жыццё, бо ў пэўны час яны не выканалі сваіх абавязкаў як сыноў, мужой, абаронцай Маці-Радзімы.

“О, К ры ўск ая з я м я..." (1924). У гэтым вершы В. Ластоўскі выказвае абвінавачванне сучаснікам-крыўцам, а таксама іх бліжэйшым продкам, якія давялі Крыўскую зямлю да такога стану, калі яна зняслайлена, // свабодь любае здавён пазбайлена, (...) не валадарная // і не магутная, // раба бяздомная, раба пакутная..." (224). Абяздолены стан Крыўскай зямлі, паднявольнае жыццё крыўцой- правечных рабоў чужое думкі - з'яўляецца, акрамя іншага, вынікам невыканання імі аднаго са сваіх спрадвечных абавязкаў: абароны Айчыны. Менавіта да гэтага заклікаў В. Ластоўскі сваіх суайчыннікаў у ахарактарызаваным вышэй вершы "Благаслаўлён сын...".

Форму верша "О, Крыўская зямля..." можна вызначыць як зварот-пытанні лірычнага героя (аўтара) да сваёй Айчыны (Крыўскай зямлі) і адказы на іх.

Твор складаецца з трох сэнсаўтваральных частак.

Вялікая літара ў займенніках-адрасатах кожнай з частак верша падкрэслівае адносіны лірычнага героя (яго грамадзянская пазіцыя су- 
падае $з$ аўтарскай) да Радзімы з пашанай. У той жа час павага, якая павінна шырока праяўляцца з боку яе грамадзян да Бацькаўшчыны, у аб'ектыўнай рэальнасці, што характарызуецца у дадзеным творы, адсутнічае. У вершы Крыўская зямля і яе дзеці - гэта аб'екты паэтычнага асэнсавання і характарыстыкі, якія існуюць нібы самі па сабе. Крыўская зямля і яе дзеці - аб'екты адной прасторы, якія па вызначэнні павінны быць разам, аднак яны існуюць паасобку, самі па сабе. Радзіма-маці знаходзіцца $\ddot{y}$ бядотным і гаротным стане. I гэта пры тым, што раней (пра гэта - у другой частцы верша) яна мела славу гуиную, якую здабывалі яе сыныл. Цэнтральныя вобразы верша - Радзіма-маці і яе сыны - супрацьпастаўлены ў рэальнасці, якую уззнаўляе лірычны герой.

У вершы "О, Крыўская зямля..." ускосна прадстаўлены плач, галашэнне Крыўскай зямлі з той прычыны, што яе дзеці выракліся яе і гэтым самым прывялі да гаротнага стану. Дзеля пацвярджэння дадзенай гіпотэзы звернемся да характарыстыкі вобразаў верша.

П ершая ч ас т ка. У ёй канстатуецца сацыяльны заняпад Крыўскай зямлі.

У пытаннях гэтай часткі адначасова прысутнічаюць і сцверджанні пра гаротны стан Айчыны. Яна пазбаўлена славы (зняслаўлена), якая была раней; гэтая слава згадваецца ў наступнай частцы твора. Крыўская зямля свабоды пазбаўлена - такое паэтычнае сцверджанне падкрэслівае паднявольны стан Айчыны, якая раней мела дзяржаўную незалежнасць. I першае, і другое з прыведзеных сцверджанняў ускосна звяртае ӱвагу на мінулую славу і незалежнасць гэтай часткі славянскай прасторы.

Чаму Тьь поішся // Слязьмі гаручьмі? // Чаму Тьь пойнішся бядой пякучаю?.. (223). Паэтычныя вобразы гэтай часткі верша (слёзы гаручьля, бяда пякучая) падкрэсліваюць глыбіню гаротнага стану маці-Айчыны, а дзеясловы поішся, пойнішся - безвыходнасць, абсалютнасць, невымернасць яе гора. Акрамя таго, такі стан Крыўскай зямлі вельмі востра, балюча перажываецца ёю. Тут В. Ластоўскі дае паэтычныя тэзісы, якія ў наступных радках гэтай і другой часткі ён разгорне і праілюструе пры дапамозе гістарычных сведчанняў і абвінавачванняў суайчыннікам.

Сэнс сцверджання-метафары зямля крыві разгортваецца ў другой частцы верша. Тут жа адбываецца паэтычная гутарка пра тое, што краіна з гераічным мінулым знаходзіцца у стане рабыні: не валадарная // i не магутная, // раба бяздомная, // раба пакутная... (224). Такія вобразныя вызначэнні падкрэсліваюць не толькі паднявольны 
стан краіны, а і ў некаторай ступені абсалютную бесперспектыўнасць такога яе існавання, пры якім няма сапраўднага валадара, што выведзе краіну з такога стану, што створыць умовы для магутнасці Крыўскай зямлі, умацавання яе дзяржаўнага будынка як трывалага, устойлівага.

У дадзеным вершы лік Крыўскай зямлі загіджаны, красы пазбаўлены, сама яна зняслайлена, // пакрыйджана, // ў славян сям'і паніжана (224). Такімі высновамі паэт звяртае ӱвагу сучаснікаў на тое, што цяперашні стан Радзімы - гэта трагічны вынік паднявольнага яе становішча, у якім вінаватыя і яе грамадзяне. Абсалютызуючы зняслаўленасиь Крыўскай зямлі, В. Ластоўскі ўскосна абвінавачвае суайчыннікаў у грамадзянскай нядбайнасці і ў той жа час апасродкавана імкнецца абудзіць іх грамадзянскае сумленне.

Другая частка. Тут лірычны герой адсылае чытача да тых перыядаў з гісторыі Крыўскай зямлі, калі яе сыныь сваёй крыьёй куnлялі славу гучную Радзіме. У гэтай частцы не толькі ўсхваляецца такі час, a і ўскосна падкрэсліваецца абсурднасць цяперашняга (на момант паэтычнай гутаркі) стану Крыўскай зямлі. Радзіма лірычнага героя (аўтара), маючы слаўныя гістарычныя перамогі, павінна была б красавацца сярод славянскіх краін. Аднак такое не адбываецца. Лепшыя яе сыны палеглі $\ddot{\mathrm{y}}$ касиістым вале барацьбе. Тыя ж, хто цяпер мог бы ўзняцца на абарону Радзімы, сталі правечнымі рабамі чужое думкі.

У чым жа прычына той грамадскай з'явы, на якую звяртае ўвагу В. Ластоўскі?

Гаротньия крыйцы // ламалі косці за чужую справу, // сваёй крывёи і мазалём // ішлі купляць чужынцам славу (224). Імкненне да чужога прывяло да таго, што крывічане сталі правечнылі рабамі чужое думкі, якія жадалі прыгону лепшьля варункі. Асаблівае значэнне $\breve{y}$ такім паэтычным кантэксце мае вобразная канстатацыя раб. Нашчадкі былых слаўных грамадзян сваёй Айчыны заклалі падмурак паднявольнага існавання роднага краю. Раб не атрымае права не толькі на чалавечыя уммовы яго існавання, а і на будучыню, калі ён не ўзыдзе на шлях пратэсту супраць свайго паднявольнага існавання.

Прыгадаем у сувязі з гэтым наступныя факты. Верш напісаны у эміграцыі, у той перыяд, калі В. Ластоўскі яшчэ выконваў функцы кіраўніка эміграцыйнага ўрада Беларускай Народнай Рэспублікі. Да гэтага часу змаганне за БНР яе уррада на тэрыторыі Беларусі і Латвіi (1918-1920) адышло ў гісторыю; яе абаронцы былі альбо знішчаны, альбо знаходзіліся ў эміграцыі. У сувязі з гэтым варта пры- 
гадаць хаця б гісторыю Слуцкага ўзброенага паўстання 8 , верш Янкі Купалы "25.III.1918 - 25.III.20 (Гадаўшчына-памінкі)", апавяданне Васіля Быкава "На чорных лядах" і інш. У Беларусі ж гэтага часу трывала ўсталявалася савецкая ўлада, а сама краіна стала часткай новага дзяржаўнага ўтварэння: СССР. Самастойнасць Беларусі, як і іншых саюзных рэспублік, была адноснай. Відаць, гэтыя і іншыя факты паспрыялі таму, што В. Ластойскі ў вершы “О, Крыўская зямля..." канстатуе прывычку (правечны раб чужое думкі прывылк (...)) суайчыннікаў чужых багой // ў чужацкай мове славіщь, // з чужьны браць чужацкі полер // $i$ чиіџь чужь на сцягах колер (224). Крьйubl-рабы аказаліся у у такой грамадскай сітуацыі, калі яны не проста рабы чужое думкі, а паднявольныя, якія нясуць свае чужьицам думьл, // адзетьля ў чужаику шату, // i верньля (...) сваёму кату... (225). Раб адданы свайму кату - у гэтым выключная абсурднасць грамадскага існавання на Радзіме ў асэнсаванні В. Ластойскага. Такое рабскае становішча грамадзян прывяло да таго, што іх краіна стала не валадарнай рабой. Гэта значыць, яна нічым не валодае, не можа вырашаць свой лёс, мець годных спадкаемцаў. Такое рабскае становішча краіны і яе грамадзян мела яшчэ адзін вынік: крыйць пачалі ўжываць у ежу не сапраўдны хлеб, а з дамешкай яловай кары (Дылк вось чаму крылеи // кару яловую ў хлеб мяшай). Прыгадаем: у народнай традыцыі хлеб - сімвал жыцця; ён - неабходны для існавання і жыцця сродак. Такое параўнанне можна спраецыраваць на цытаваную вышэй выснову з верша “О, Крыўская зямля...". У дадзеным кантэксце хлеб можа ўспрымацца не толькі як харч для падтрымкі фізічных сіл, а і як

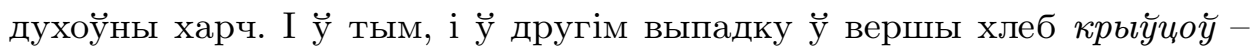
гэта сурагат; харчаванне ім не прыносіць карысці. Зерне ж для лепшага хлеба Чужыя каланісты (...) стругамі гналі ў Рыгу (225).

Пытанне $A$ нам то што? (225) мае двайны сэнс. Па-першае, яно ўскосна сцвярджае, што крызйам у такой сітуацыі рабавання краіны нічога не застаецца, нават хлеба. Па-другое, яно ўтрымлівае у сабе іранічны падтэкст. Параўнаем з выслоўем $A$ мне што да гэтага? (мяне гэта не тычыцца). Такое аб’ектна накіраванае сцверджанне сінанімічнае фразеалагізму Мая хата з краю. Ахарактарызаваныя вышэй часткі верша “О, Крыўская зямля...” пацвярджаюць менавіта такі

8 Пра гэта: Слуцкі збройны чын 1920 г. У дакумэнтах і ўспамінах, Ул. Ляхойскі, Ул. Міхнюк, А. Гесь, Мінск 2006; В. Прокулевич, Слуцкое восстание, "Неман" 1996, № 4, с. 149-196; Н. Стужынская, Dei minoris [Да 75-годдзя Слуикага збройнага чыну], "Літаратура і мастацтва" 1995, 24 ліст., с. 14-15. 
- другі з прадстаўленых тут - сэнс працытаванага пытання з гэтага твора. Крыўцы робяць выгляд, што разбуральныя адносіны чужынцаў да Крыўскай зямлі іх не тычацца; яны абыякавыя да гэтага. Такі падтэкст яшчэ болей падкрэслівае грамадскі трагізм верша. Ён пацвярджаецца таксама перадфінальнымі радкамі: Паном іx панскі Бог спрьяяе.. // У нас свайго няма.. // А Дзедка-Дамавік, // той штось гуляе... (225).

У сітуацыі, калі ўжо няма свайго Бога, наўрад ці хто і што дапаможа насельнікам Крыўскай зямлі. I нават Дзедка-Дамавік адмаўляецца ад выканання сваіх спрадвечных абавязкаў. Параўнаем прыведзеную вышэй выснову з фактамі ўсходнеславянскай міфалогіi.

Дамавік - (...) дух дома, ахойнік дамашняга ачага. (...)

[Ён. - A.M.] спрыяе хатняй гаспадарцы, нябачна дапамагае членам сям'і ва ўсіх іх справах (...) Дамавік таксама папярэджвае людзей аб будучых няшчасцях - пажары, крадзяжы, хваробах. У той жа час Дамавік можа быць капрызлівым, нават злосным, калі людзі яго не паважаюць, не прытрымліваюцца старых традыцый, часта сварацца, не дапамагаюць жабракам ${ }^{9}$.

Такім чынам, грамадская пасіўнасць крыйцой, ігнараванне імі спрадвечных абавязкаў перад лакальнай прасторай, у якой існуе чалавек, з'яўляецца прычынай іх безабароннасці у шырокай быційнай прасторы. Гэта падкрэсліваецца пры дапамозе вобраза пашыранага ў народзе міфалагічнага духа - Дамавіка: ён адвярнуўся ад тых, каго павінен быў бы абараняць. Дом крыиццой застаўся без ахойнага духа, ён адкрыты для разбурэння.

Трэцяя частка (фінальныя радкі-вывад). $O$, Крьйская зямля! // O, волатаў нашчадкі!.. (225). У гэтых эмацыйна-ацэначных сказах прачытваецца ўзаемавыключальны сэнс. У першым сказе, думаецца, утрымліваецца захапленне Радзімай, якая, нягледзячы ні на што, застаецца яшчэ жывой, трывала стаіць на зямлі. Гэта можна растлумачыць клічнікам, які сцвярджае такое захапленне лірычнага героя. У другім жа сказе, акрамя клічніка, ёсць і шматкроп'е. Яно, відаць, падкрэслівае расчараванне, нежаданне далей весці гутарку пра нашчадкаў волатай.

У апошнім сказе верша чытаецца, нягледзячы на яго клічную інтанацыю, наступнае рытарычнае пытанне: што можна чакаць ад

9 У. Коваль, Народныля уัяўленні, павер'і і прыкметы: Даведнік па ўсходнеславянскай міфалогіi, Гомель 1995, с. 54-55. 
ахвяр нядаўняй гістарычнай і цяперашняй нядбайнасці насельнікай Крыўскай зямлі?

Такім чынам, змест гэтага твора (плач, галашэнне Крыўскай зямлі) з'яўляецца канцэпцыйным працягам паэтычнай гутаркі В. Ластойскага пра лёс Радзімы, прадстаўленай у вершы "Благаслаўлён сын..." . Гаротныл крыйцы ў лірычнай прасторы верша "О, Крыўская зямля..." ствараюць перадумовы іх пракляцця як нацыі.

У выніку прапанаваных вышэй назіранняў і высноў можам пацвердзіць вызначаную у пачатку артыкула гіпотэзу пра эстэтычную лірычную канцэпцыю патрыятычнага зместу ў вершах В. Ластойскага.

У прамове на V Асамблеі Лігі Нацый, якая адбылася у Жэневе у верасні 1924 г. ("Прамова ў Жэневе"), В. Ластоўскі вельмі катэгарычна характарызаваў паднявольнае, на яго погляд, становішча савецкай Беларусі (354-359). Аднак пасля прыезду ӱ Беларусь у 1926 годзе (увосень гэтага года праводзілася навуковая канферэнцыя па праблемах рэформы беларускага правапісу) ён прымае рашэнне аб вяртанні на Радзіму. Відаць, першыя вынікі працэсу беларусізацыі пераканалі В. Ластойскага ў тым, што ў Беларусі адбываюцца тыя грамадскія змены, пра якія ён марыў як асветнік-адраджэнец ("Уражанні з паездкі у Беларускую Радавую Сацыялістычную Рэспубліку" В. Ластоўскага адлюстройваюць яго назіранні некаторых грамадскіх працэсай на Радзіме $\ddot{y}$ гэты час). В. Ластойскі пасля вяртання ў Беларусь актыўна ўключаецца ў грамадскае і навуковае жыццё краіны. Аднак у 1930 годзе ён быў арыштаваны як "вораг народа"; пасля паўторнага арышту у 1937 годзе 23 студзеня 1938 года былы сакратар "Нашай нівы”, былы старшыня Рады міністраў БНР, былы акадэмік і неадменны сакратар БАН быў расстраляны.

"Паэ т, ты вольн аг а Пег ас а..." (1923). Гэты верш-заклік мае два метафарычныя сэнсаўтваральныя аспекты.

Пе ршы ас пек т: агучваецца літаратурна-эстэтычны погляд аўтара на форму і змест мастацкага твора: Паэт, тьл вольнага Пегаса // ў прыгожых дум ярмо ўпрагай // $і$ тучны чарназём // мінуйшчьльь радзімай // у скібы стройныя складай! (215).

Другі ас пек т: сцвярджаюцца прычыны, падставы для сфармуляванага ў пачатку верша эстэтычнага сцверджання; прапанойваецца яго вобразны доказ. Бо толькі гэта глеба // дасць нам жаданы агняквет, // якім крывічкі геній // счаруе свет. // Бо толькі родньи чарназём, ияплом духовым абагрэт, // здалее даџь пітомнае красы // праўдзівы квет (215). 
Вызначым сэнсаўтваральную ролю адпаведных вобразаў у кожным $з$ вылучаных вышэй аспектах.

Вольны Пегас: у кантэксце верша - сімвал творчасці, натхнення.

Запрэжаньи ӱ прыгожых дум ярмо Пегас. Гэты вобраз нібыта супрацьстаіць, супярэчыць вызначанаму вышэй: вольны Пегас быццам бы супрацьпастаўляецца пад'ярэмнаму Пегасу, які павінен быць запрэжаньл у ярмо (ярмо - сімвал цяжкай, паднявольнай працы). У сувязі з гэтым прапануем наступную тэзу: паміж вызначанымі вышэй вобразамі Пегаса не існуе ні супрацьпастаўлення, ні супярэчнасці; другі з вылучаных вобразаў развівае, удакладняе папярэдні.

Прымаючы пад увагу той факт, што вольны Пегас - гэта сімвал творчага натхнення (яно не падначальваецца ніякаму загаду), прапануем наступныя доказы агучанай тэзы. Па-першае, натхненне - гэта толькі адна з перадумоў здзяйснення жадання паэта выказацца пры дапамозе пэўнай мастацкай формы, аздобіўшы яе адпаведным зместам. Па-другое, дадзеная перадумова застаецца толькі намерам, калі паэт не накіруе сваё натхненне $\ddot{y}$ вусце яго творчай рэалізацыі, працэс якой схематычна можна прадставіць наступным чынам: асэнсаванне творчага узздыму - пошук формы выказвання - асэнсаванне вобразаў выказвання - напаўненне абранай формы вобразным зместам пры дапамозе спалучэння, яднання, суаднясення адпаведных вобразаў і інш. Па-трэцяе, працэс ад вольнага натхнення да яго рэалізацыі ў выглядзе літаратурнага твора, нават калі ён дастаткова хуткі (верш напісаны за кароткі час), - з'ява, якая вымагае ад творцы напружання яго творчых, духоўных, душэўных сіл. Па-чацвёртае, пасля працэсу "матэрыялізацыі" вольнага натхнення наступае перыяд творчай адказнасці паэта: перад сабой, зместам яго натхнення, рэцыпіентам вынікаў натхнення, твора, спадчыны, урэшце - самога творцы. Такім чынам, вольны Пегас творчасці застаецца вольным толькі да таго часу, пакуль ён існуе на ўзройні творчага памкнення, азарэння, ідэі, жадання. Працэс жа рэалізацыі акрэсленага вышэй - гэта з'ява цяжкая, падпарадкаваная складанаму працэсу сэнсатворчасці шляхам спалучэння прыгожых дум (у лірыцы - вобразаў). У дадзеным выпадку другі з вылучаных вышэй вобразаў (Запрэжаны у прыгожых дум ярмо Пегас) развівае ў ідэйных адносінах першы (Вольнь Пегас) у яго праекцыі на працэс і задачы паэтычнай творчасці.

Тучны чарназём мінуўшчыны шчаслівай - вобраз, які арыентуе на адно з важных сэнсаўтваральных складаемых твораў грамадзянскага зместу. Яны павінны быць напойнены фактамі мінулага, якія у сваю 
чаргу з'яўляюцца ўрадлівым сэнсайтваральным “угнаеннем" ( mучнылм чарназёмам) у мастацкай прасторы твора.

Стройньля скібы гістарычных фактаў (мінуўшчьны) літаратурнага твора - дасканалая форма іх спалучэння, аб'яднання ў адзіную ідэйную глебу твора (-ай).

Жадань агняквет літаратурнай спадчыны крьвічкага генія - гэта вынік творчых намаганняў, якія сцвярджаліся ў папярэдніх радках верша. Сутнасць такога выніку ў тым, што літаратурны твор (-ы), напойнены гістарычным зместам, увасобленым ва ўдалай форме, дазволіць рэалізаваць адну з важных місій нацыянальнай літаратуры: сцвярджэнне яе эстэтычнай значнасці не толькі ў нацыянальнай культурна-мастацкай прасторы, а і ў такой жа прасторы іншых народаў. У сувязі з адзначаным вышэй варта прыгадаць наступную выснову В. Ластойскага, агучаную ім яшчэ $\breve{y} 1914$ годзе (артыкул "Па сваім шляху").

Няхай хто-небудзь $з$ нашых пісьменнікаў напіша хоць адну рэч, каторая бы паказвала новыя дарогі чалавецтву, і не будзе на свеце знаючага літаратуры народа, каторы бы пасля гэтага, хто і што такое беларускі народ, не ведаў.

(...)

Адзін геніяльны твор, напісаны па-беларуску, можа даць славу і пашану нашаму народу (284).

Родньл чарназём, які ияплом духовьлм абагрэт, - слаўныя гістарычныя факты, абагрэтыля (выпешчаныя, узгадаваныя, пераканальна рэпрэзентаваныя) альбо духам цяпла (полымя, кастра) творчых аўтарскіх намагання ў, альбо цяплом душы паэта.

Праўдзівы квет пітомнае красы - сапраўдная (арыгінальная, праўдзівая, айтэнтычная) эстэтычная квецень, 3 якой у душы рэцыпіента можа нарадзіцца пітомная краса: прыгажосць, што ўзгадуе новыя прыгожыя формы $\ddot{y}$ (калі мець на ўвазе крывіцкі матыў гэтага верша) нацыянальнай сферы, у тым ліку літаратурнай, інтэлектуальнай, духойнай.

У вершы "Паэт, ты вольнага Пегаса..." В. Ластойскі абгрунтоўвае эстэтычную ролю нацыянальнай вобразатворчасці ̈̆ лірыцы (літаратуры). Такое абгрунтаванне падкрэсліваецца падпарадкавальным злучнікам бо, якім пачынаюцца два апошнія паэтычныя складаныя сінтаксічныя цэлыя гэтага твора.

"П і ш ы..." (упершыню апублікаваны у 1924 ). Паводле формы твор уяўляе сабой верш-заклік. 
Парайнанне высноў з артыкула Ю. Верашчакі "Сплачвайце доўг" і паэтычных сцверджанняў з верша "Пішы..." В. Ластоўскага падводзіць да меркавання, што паміж артыкулам і гэтым вершам існуе некаторая неадпаведнасць, а то і супярэчнасць.

(..) паэта (...) павінен выяўляць красу свайго народа і краю. (...) апрача драздоў, ануч, гною і пракляцця у маёй душы ёсць яшчэ шмат красы, перад маімі вачамі скрозь краса, жыццё, сонца, песні і бязмернае багацце відаў. Я хачу мець усё гэта, ператворанае ў спектры калектыўнай нашай душы - у словах нашых паэтай-прарокай. (...) я хачу з вашых твораў навучыцца бачыць каля сябе красу, каторую, я чую, што яна ёсць, але мая душа не так чутка, каб улавіць яе ("Сплачвайце доўг", 274).

У вершы "Пішы..." В. Ластоўскі заклікае ствараць літаратурныя тэксты слязьмі душы. Такім чынам сцвярджаецца напаўненне мастацкай літаратуры сумным настроем, выкліканым змрочнай рэчаіснасцю.

Пры гэтым варта заўважыць наступнае: вызначаная супярэчнасць не азначае, што погляды В. Ластоўскага на праблему “змест мастацкай літаратуры" кардынальна змяніліся ад моманту стварэння ім артыкула "Сплачвайце доўг". У артыкуле Ю. Верашчака (В. Ластоўскі) так катэгарычна выказаўся супраць змрочнага настрою ў тагачаснай беларускай літаратуры, каб, акрамя іншага, "справакаваць" дыскусію пра шляхі развіцця нацыянальнага прыгожага пісьменства.

У вершы "Пішы...", апублікаваным амаль праз адзінаццаць гадоў ад часу выхаду ў свет артыкула "Сплачвайце доўг", гутарка ідзе пра асаблівасці стварэння літаратурнага твора, які б эфектыўна ўздзейнічаў на свядомасць чытача. Дзеля гэтага павінны быць пэўныя перадумовы яго ӱзнікнення. Пра гэта якраз і адбываецца гутарка ў дадзеным вершы. Вобразы і мастацкія факты гэтага твора спрыяюць вызначэнню поглядаў яго аўтара адносна таго, як павінен стварацца мастацкі твор.

Вылучым і інтэрпрэтуем гэтыя вобразы і мастацкія факты.

Вобразы, якія акрэсліваюць, вызначаюць прадмет

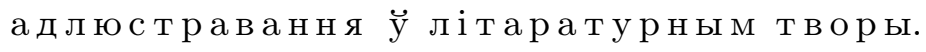

Болесиі - боль, з якім сутыкаецца чалавек у жыцці, які напаўняе яго душу і свядомасць як вынік асэнсавання неўладкаванасці, разладу, трагізму жыцця.

Жьичя пьишы - віраванне жыцця, яго бурлівыя праявы.

Глум $i$ здзек - марнатраўства жыцця, разбурэнне яго, здзек і насмешкі ў ім (паводле значэння дзеяслова глумічиа). 
Ярэмнае мадзенне - гэты вобраз арыентуе на адлюстраванне $\ddot{y}$ літаратурным творы паднявольнага - цяжкага, пазбаўленага здзяйснення жаданых мэт - існавання чалавека. Прычым абставіны такой паднявольнасці можна праецыраваць на розныя сферы адносін: грамадскую, асабовую, інтымную. Ёсць і іншы сэнсаўтваральны аспект гэтага вобраза: паднявольнасць нараджае згубнасць для яе аб'екта. Чалавек, які знаходзіцца ў ярме пэўных адносін, мадзее (марнее), г. зн. крок за крокам праходзіць шлях паступовага ўмірання у паднявольных умовах.

Трутны хлеб - сэнс дадзенага вобраза можа інтэрпрэтавацца наступным чынам.

1) Хлеб - падмурак жыцця, паказчык яго дабрабыту.

Хлеб надзённь - тое, што крайне неабходна для жьиця, для існавання ${ }^{10}$.

2. Гэты падмурак (неабходнасць) для існавання трутныл. Эпітэт

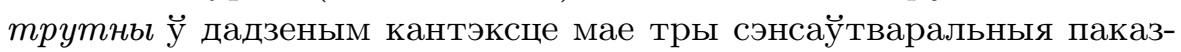
чыкі.

Трутньл хлеб - падмурак, які

а) служыць асновай для нечага іншага: больш значнага ў працэсе ўзвядзення будучых (адрозных ад цяперашніх) форм жыцця; параўнаем: трутны - ад трут (высушаная губа, якая выкарыстоўваециа пры выссяканні агню ${ }^{11}$ ), які раздзьмухваюць пасля пападання на яго высечанай крэсівам іскры;

б) зроблены ў выніку выкарыстання чужой працы, не сваіх намаганняў і высілак; параўнаем: трутавік - грыљб, які паразітуе на дрэвах, альбо: труцень (у пераносным значэнні) - той, хто не прачуе, а жыве за кошт праџь другіх; лодар ${ }^{12}$;

в) атручаны; параўнаем: труцічь - знішчачь атрутай; тручань (у значэнні дзеепрыметніка) - ад труціць; тручань (у значэнні прыметніка) - такі, якога труцілі13.

Такім чынам, у дадзеным выпадку адбываецца гутарка пра адлюстраванне ӱ літаратуры альбо тых праяў жыцця, што служаць падмуркам для больш дасканалых яго форм, альбо такіх, якія аб'ектыўна з'яўляюцца разбуральнымі ў перспектыўных адносінах: у праекцыі на будучае жыццё. I першы, і другі з вызначаных сэнсаў гэтага вобра-

10 І. Лепешаў, Фразеалагічны слойнік беларускай мовы: У 2 тамах, Мінск 1993, т. 2 , с. 526 .

11 Тлумачальньи слоўнік беларускай мовы ў пяиі тамах, Мінск 1977-1981, т. 5, кн. 1, c. 526 .

12 Тамсама, с. 526-527.

13 Тамсама, с. 527. 
за сведчыць пра тое, што В. Ластоўскі арыентуе пісьменнікаў на адлюстраванне лёсавызначальных праяў жыцця $\ddot{y}$ іх выніковасці.

Слоў каменні - гэты вобраз утрымлівае $\breve{y ~ с а б е ~ д в а ~ с э н с ы, ~ а б у м о у ̆-~}$ леныя значэннем слова "камень". Звернем увагу на фраземы, у складзе якіх ёсць назойнік камень.

Камень за пазухай - скрытая, затоеная злосць, нядобры намер, камень на сэрцы - душэўны цяжар, камень спатыкнення - значная перашкода ў якой-небудзь справе ${ }^{14}$; кідаць каменем - асуджаць, абвінавачваць, ганьбіць каго-н., сінонімы: абліваць граззю каго-н., што-н., наводзіць цень на каго-н., што-н. ${ }^{15}$;

насіць (трымаць, хаваць) камень за пазухай - затойваць злосць на каго-н., быць гатовым зрабіць што-н. дрэннае каму-н. ${ }^{16}$;

скідаць з сэрца камень - вызваляцца ад якога-н. цяжара, гнятучага пачуцця ${ }^{17}$.

Такім чынам, вызначым два сэнсаўтваральныя значэнні вылучанага вышэй вобраза.

1) Адзін з прадметаў адлюстравання ў мастацкім творы, паводле В. Ластойскага, - небяспечнасць учынку, народжанага нядобрым, злым, абвінавайчым, ганебным, дрэнным словам, - словамі-каменнямі.

2) Яшчэ адзін прадмет літаратурна-мастацкага адлюстравання цяжар на сэрцы чалавека, перашкоды у яго жыцці як вынік пэўных слой і народжаных імі злых учынкай.

Вобраз брата, які няволіиь брата - В. Ластойскі звяртае ўвагу на неабходнасць адлюстравання $\ddot{y}$ мастацкай літаратуры парушэнняй аднаго з агульнапрызнаных маральных імператывай: шанавання брата свайго. Прыгадаем у сувязі з гэтым непрыманне хрысціянскай мараллю братазабойства: гісторыю забойства Каінам Авеля і пакарання Госпадам апошняга.

Вобразам брата, які няволіџь брата, В. Ластойскі сцвярджае думку не толькі пра тое, што прадметам адлюстравання ў мастацкай літаратуры павінны быць антычалавечыя з'явы, якія існуюць у жыцці, a i (апасродкавана) тое, што вынікам падобных з'яў будзе пакаранне ix здзяйсняльнікаў. Такім чынам, В. Ластоўскі ўскладвае на паэзію (літаратуру) папераджальную, перасцерагальную місію.

Вобраз раба, які багоміць ката, пакланяецца яму, узвышае яго. В. Ластойскі звяртае ўвагу на знішчальную для чалавека (яго асо-

14 І. Лепешаў, Фразеалагічны слойнік беларускай мовыл.., т. 1, с. 482.

15 Тамсама, c. 504.

16 І. Лепешаў, Фразеалагічны слойнік беларускай мовы..,, т. 2, с. 78.

17 Тамсама, с. 342. 
бы, жыцця) з'яву-разлад: схіленне перад сілай, перад знішчальнымі праявамі жыцця. Відаць, для таго, каб падобная з'ява не пашырала-

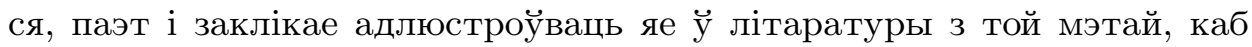
рэцыпіент адчуё, зразумеў, што і ён сам можа аказацца у становішчы раба, які схіляецца перад сваім катам і ўзвышае яго. Такім чынам, прыгожае пісьменства павінна ўзяць на сябе функцыю грамадскага папярэджання.

Названыя вышэй два вобразы з верша В. Ластоўскага "Пішы..." на уззройні паказальных прыкладаў звяртаюць увагу на абсурднасць прататыпнай рэчаіснасці, сутнасць якой (абсурднасці) - у адмаўленні маючага быць і прыманне анамальнага, выродлівага, аб'ектыўна зніжанага і пачварнага. У сувязі з гэтым паэт і заклікае адлюстроўваць у мастацкіх формах такія разбуральныя для свядомасці чалавека і рэчаіснасці з'явы.

Стогн душы - гэты вобраз вызначае адлюстраванне $\ddot{y}$ літаратурным творы парыванняў, пошукаў, сумненняў, пакут, разбурэння спадзяванняу і інш. у душы паэта. Чаму сэнс двух лексічных складнікаў дадзенага вобраза тлумачыцца ў гэтым выпадку пры дапамозе такога доўгага кантэкстуальна сінанімічнага раду? Стогн у прамым яго значэнні з'яўляецца вынікам фізічнага (часцей за ўсё невыноснага) болю чалавека. Такому стогну папярэднічае цэлы шэраг абставін: нагоды для уззнікнення болю, працэс яго пашырэння, цыклічнасць і інш. Канстатаванае вышэй можна спраецыраваць і на душу чалавека, стогн якой з'яўляецца вынікам цэлага комплексу абставін, прычынна-выніковых узаемадзеянняў. Стогн жа душы пісьменніка, які ён, паводле В. Ластоўскага, павінен адлюстроўваць у сваіх творах, гэта не толькі адлюстраванне гэтай з'явы як такой, а і працэс мастацкага асэнсавання тых праяў, што нарадзілі яе.

Умовы, якія дапамогуць паэту (пісьменніку) доказна, прыгожа, хвалююча, пабуджальна адлюстра ваць праявы рэчаіснасці ̈у мастацкім творы.

Пішы нервамі, крывеёи душы - вызначаецца адна з умоў пераканальнага адлюстравання рэчаіснасці і яе супярэчнасцей у мастацкай літаратуры: духойнае, душэўнае ўзрушэнне пісьменніка.

Пішы ўзрыгамі [парываннямі, памкненнямі - A.M.] душы - умова напаўнення твора непаўторным светам і арыгінальным зместам.

Гэтыя вобразныя заклікі падкрэсліваюць, акрамя іншага, што літаратурная творчасць з'яўляецца вынікам глыбокага нервовага і псіхалагічнага напружання пісьменніка. У той жа час яна знясільвае яе здзяйсняльніка. Правядзём наступную аналогію. Калі чалавек страч- 
вае пэўную колькасць крыві, ён памірае. Душэўная крой пісьменніка, якую ён аддае творчасці, - гэта своеасаблівая форма яго самаахвярнасці. Пісьменнік - донар духоўнасці; ён добраахвотна прымае пакуты духойнага напружання як спадарожніка мастацкай творчасці.

Сябе распні на крыжу мук - крыж мук пісьменніка - гэта ӱвасабленне пакут свядомасці ў пошуках шляхой вырашэння праблем рэчаіснасці у мастацкім творы; такія мукі з'яўляюцца вынікам асэнсавання недасканаласці чалавечых адносін. Распінаючьл сябе на крыжы пакут творчасці, пісьменнік тым самым робіць свой твор больш пераканальным, праўдзівым, доказным. Крыж мук-гэта ў той жа час духойнае, маральнае, творчае выпрабаванне для пісьменніка, якое ён мусіць вытрымаць у працэсе мастацкай творчасці. Такія выпрабаванні, калі гутарка ідзе пра сапраўдную літаратуру, немагчыма абысці. Болевае напаўненне мастацкага твора перадаецца яго рэцыпіентам, якія ў выніку могуць прыйсці да ўсведамлення неабходнасці змены ўласнага жыцця такім чынам, каб падобны боль як вынік разладу жыцця не ўзнік альбо не паўтарыўся у іх існаванні.

Надзеі спапялі - знішчы, ператвары ў попел - у дадзеным выпадку канстатуецца неабходнасць знішчэння марных спадзяванняў, тых, якім не дадзена здзейсніцца.

А чысиі сэриа ў агні иярпення - сцвярджаецца духоўнае ачышчэнне творцы, а праз гэта - яго духоўнае ўзвышэнне. Такое ўзвышэнне праз цярпенне - з'ява пакутлівая, балючая; яно агонь, які не толькі знішчае непатрэбнае, a і яшчэ абпальвае таго, хто яго разводзіць.

Усіх багой $і$ стодаў, // кром міласиі $к$ народу, // ты пакрышы - В. Ластойскі, відаць, акцэнтуе ӱвагу паплечнікаў па стварэнні прыгожага пісьменства на яшчэ адну ўмову літаратурнай творчасці: на пазбаўленне ад хісткіх "ідэалаў". Пацвярджэннем прыведзенаму вышэй меркаванню можа быць наступнае. Паэт выкарыстоўвае ў першым 3 цытаваных радкой назоўнік бог у множным ліку. Пакінуўшы без каментарыяў той факт, што В. Ластоўскі не выключаў з духойнай беларускай прасторы духойны вопыт паганскага веравызнання i, адпаведна, паганскіх багой, прыгадаем некаторыя з запаветаў Свяшчэннага пісання. Чалавек мусіць верыць у адзінага Бога; пакланенне іншаму богу, стварэнне куміраў вызначаецца у гэтай крыніцы як грахоўная з'ява (Зыход 20: 1, 3-6).

У вылучаным вышэй кантэксце верша Пішы..." яго аўтар, можна меркаваць, сцвярджае неабходнасць разбурэння, знішчэння штучна створаных ідэалаў. 
Для больш поўнага выяўлення сэнсу парады В. Ластоўскага Усіх багоў $i$ стодаў, // (...) mbl nакрышыь варта растлумачыць значэнне лексемы стоды у г гэтым кантэксце. Паколькі такога слова у "Расійска-крыўскім (беларускім) слоўніку" В. Ластойскага (Коўна, 1924) няма, то мэтазгодна звярнуцца да іншых лексічных крыніц таго часу, каб справіцца $з$ акрэсленай вышэй інтэрпрэтацыйнай задачай. У "Беларуска-расійскім слойніку" М. Байкова і С. Некрашэвіча ёсць падобнае слова: стоднік. Аўтары гэтай крыніцы падаюць наступны яго пераклад на рускую мову: 1) скотник, 2) сторожевая собака при стаде, 3) племенной бык ${ }^{18}$. Калі ў якасці зыходнага для інтэрпрэтацыі возьмем другі сэнс назойніка стоднік і паставім яго ў кантэкст цытаванай вышэй часткі верша "Пішы...", то яе сэнс гіпатэтычна можна растлумачыць наступным чынам. В. Ластойскі адмаўляе "ісціну", што належыць вартаўнікам статку ілжэбагой, іх абаронцам, пасрэднікам паміж Богам і чалавекам.

У сувязі са зробленым вышэй вывадам адносна руйнавання штучна створаных ідэалаў паставім наступнае пытанне. Чаму павінна адбывацца менавіта разбурэнне, а не, скажам, асэнсаванне у цэлым, па частках, у сукупнасці састаўляючых сістэмы ідэалаў (сутнасці розных багой), як гэта вынікае з першага лексічнага значэння дзеяслова $n a$ крышшыць?

Пакрышыць - раскрышыць, нейкую колькасць чаго-н. або ўсё, многае; напрыклад, нарэзачь дробнылі кавалачкамі што-н. ${ }^{19}$ для таго, каб потым прыгатаваць нешта. Гэты дзеяслоў мае і другое значэнне. Пакрышыць - паламачь на дробныля часткі што-н..20: разбурыць, знішчыць.

Думаецца, менавіта апошняе 3 прыведзеных вышэй значэнняў утрымліваецца ў кантэксце сцверджання Усіх багой $i$ стодаў, // кром міласиі $\kappa$ народу, ты пакрышыл. Яно падкрэсліваецца злучнікам кром (акрамя), які акцэнтуе ўвагу на выключэнні чагосьці з шэрагу пэўнай наяўнасці.

Такім чынам, у дадзенай частцы верша "Пішы..." паэт вызначае для працэсу мастацкай творчасці адзіна трывалы ідэал сацыяльных адносін: міласць да народа, якая (у сваю чаргу) павінна натхняць творцу на працэс адлюстравання адпаведнай рэчаіснасці ̈̈ прыгожых мастацкіх формах, можа стаць адной з рухаючых сіл мастацкай творчасці.

18 М. Байкоў, С. Некрашэвіч, Беларуска-расійскі слойнік, Мінск 1926, с. 299.

19 Тлумачальны слоўнік беларускай мовы.., т. 3, с. 621.

20 Тамсама, с. 621. 
Умовы ўзнікнення мастацкага твора, паводле верша В. Ластоўскага "Пішы...", наступныя: неспакойны, узрушаны, пакутны, цярплівы стан свядомасці і душы пісьменніка.

У наступнай частцы верша "Пішы..." (Й niшы: (...) свой mвор вяршы) В. Ластоўскі на вобразным узройні рэпрэзентуе тыя з'я в ы і аб'екты рэчаіснасці, якія “даюць” паэту сэнсайтваральны “матэрыял" для літаратурнага твора (часткова тут адбываецца гутарка і пра стыль адпаведнага мастацкага адлюстравання).

Паэт звяртае ўвагу на аб'ёмнасць вобразнага адлюстравання ў мастацкім творы. Падобнай аб'ёмнасці у вершы самога В. Ластоўскага спрыяе наступная асаблівасць: кожны з вобразаў дапаўняе сэнс папярэдняга, спрыяючы гэтым самым пашырэнню меж вобразнага рэканструявання сацыяльнага бязладдзя і яго праяў.

Звернем увагу на тыя з'явы, адлюстраванне якіх, паводле аўтара гэтага твора, дапаможа пісьменніку дасягнуць наступных вынікаў: а) узнавіць у літаратурнай форме праявы разбуральнай у адносінах да чалавека прататыпнай рэчаіснасці (журба сіротная, смага гаротная, самота ўдовая, пакрыўда братняя, тульба бясхатняя); б) напойніць твор адпаведнымі пачуццямі, адчуваннямі, душэўнай цеплынёй аўтара і яго герояў, духоўным вопытам акаляючай прасторы (сардэчная туга, мілуючая душа, апары зямлі); в) ідэйна ўзмацніць вобразны кантэкст твора (чарьи мінуўшчьльь).

Журба сіротная - вынік безабароннасці, абяздоленасці вялікай, паказальнай колькасці пакрыўджаных. Не журбой сіраты, а журбой $c i$ ротнаю (тут ёсць адценне зборнасці) павінен пісаць пісьменнік; гэта значыць, калі не ўсіх сірот журбой, то мноства іх. Стыль такога адлюстравання, каб ён эфектыўна ӱздзейнічаў на чытача, мае быць тужлівым, маркотным, напоўненым пачуццём смутку па страчаным і не дасягнутым.

Смага гаротная - настойлівае, дакучлівае адчуванне чалавекам-сіратой адсутнасці тых з'яў, умой існавання, якія яму неабходныя. Эпітэт гаротная падкрэслівае татальнасць грамадскай смагі. Такім чынам, адна з задач мастацкай літаратуры - адлюстраванне памкненняй той часткі грамадства, якая перажывае, адчувае неабходнасць (смагу) у нечым важным, істотным для сябе, - таго, без чаго існаванне калі не немагчымае, то дастаткова цяжкае. Паколькі працэс дасягнення гэтай неабходнасці даволі складаны, можа быць працяглым, пакручастым, то мастацкая літаратура якраз і павінна адлюстроўваць цяжкасць, гаротнасць гэтага шляху. 
Самота ўдовая - безабароннасць, адзінота чалавека, гэтыя праявы з'яўляюцца вынікам страты (альбо разбурэння) нечага важнага ў жыцці, напрыклад, падмурка фізічнага і духойнага існавання, ідэалаў, мар і інш. Параўнаем: удава - жанчына, якая страціла мужа, а значыць, ні яна, ні яе дзеці не маюць абаронцы, кармільца; удава ў народным разуменні безабаронная перад людзьмі і светам: за яе няма каму заступіцца. Страты і безабароннасць чалавека прыводзяць яго да стану адзіноты (параўнаем: samotność (польск.) - адзінота), адасобленасці ад іншых людзей. Самота ўдовая - гэта адна з перадумоў асэнсавання шляхой выйсця са свету, які поўніцца разбуральнымі праявамі.

Пакрыўда братняя - крыўда брата, што сталася вынікам з'явы, пра якую гутарка ішла ў пачатку гэтага верша, - брат няволіиь брата.

Тульба бясхатняя - бадзянне сіраты, гаротніка, удавы, якія страцілі абарончую прастору: сцяну, дах, хату, што маглі б даць прытулак (хаця б зацішак) ад әлуму $i$ здзеку, якія чыняцца у адносінах да бясхатніка. У гэтым вобразе кожны з яго складнікаў удакладняе і дапаўняе адзін аднаго. У сувязі з адзначаным вышэй звернем увагу на лексічныя значэнні дзеяслова туляциа: 1) блукащь, хадзіџь без пэўнай мэты; бадзячиа; 2) быць бяздомньлм, беспрытульныцм²1.

Сардэчная туга - сардэчная прыгнечанасць, скруха, смутак як аўтара твора, так і яго герояў; гэта эмацыйная сфера, што павінна (бяром пад увагу загадны лад дзеяслова nicaџь у назве і тэксце верша) акрэслівацца, развівацца ў сувязі з праявамі, адлюстраванне якіх сцвярджаецца папярэдне канстатаванымі вобразамі дадзенага твора.

Мілуючая душа - стан душы аўтара і яго герояў, сфера ўзвышаных, абарончых пачуццяў і памкненняў, накіраваных у бок cipambl, гаротніка, удавы, пакрыйджанага брата.

Зямлі апары - нацыянальны, агульначалавечы духойны патэнцыял як падмурак для больш прыдатнай мадэлі сацыяльных адносін у параўнанні з той, адлюстройваць якую заклікае В. Ластоўскі ў папярэдніх радках верша. Аnары [рошчыны. - A.M.] зяллі у у мастацкім творы - гэта тыя ўзоры, прыклады 3 духоўнай сферы, асэнсаванне якіх сіратой, гаротнікам, удавой, пакрыуджаным братам можа (як тыя дрожджы або закваска ў рошчыне) стаць штуршком, глебай для уззнікнення новых праяў сацыяльнага (у дадзеным выпадку) існавання. Формы такога штуршка: думка, памкненне, учынак.

21 Тлумачальны слойнік беларускай мовы.., т. 5., кн. 1, с. 548. 
Чары мінуўшчыны - фактычнае падмацаванне фактамі гісторыі апарам зямлі з літаратурнага твора. Важным паказчыкам для інтэрпрэтацыі дадзенага вобраза з'яўляецца наказ В. Ластоўскага чарамі мінуўшиыны вяршыць літаратурны твор. Беручы пад увагу той факт, што ў створаных В. Ластоўскім у гэтым вершы вобразах аб'ядноўваюцца некалькі значэнняў пакладзеных у іх аснову прадметаў, з'яў і інш., можам сцвярджаць наступнае. Чары мінуйшчыны - гэта, акрамя іншага, ідэйнае натхненне, узор, запавет і інш., якія пісьменнік перадае $\ddot{y}$ якасці канчатковага рашэння (парады, наказу) сіраче, гаротніку, удаве, пакрыўджанаму брату.

У фінальных радках верша "Пішы" зноў (яшчэ раз) вызначаецца неабходная ўмовастварэння мастацкага тэксту.

Слязьмі душы niшb!! Калі ў пачатку твора гутарка ішла пра такі аб'ект адлюстравання у мастацкай літаратуры, як стогн душы, то у дадзеным выпадку сцвярджаецца адна з умой стварэння мастацкага тэксту: узрушаны стан душы яго аўтара. Слёзы душы - гэта вынік адпаведных працэсаў, пэўных з'яў: пакаяння, ачышчэння, дыскамфорту, дысгармоніi, разбурэння і інш. Значыць, В. Ластоўскі ў фінале верша "Пішы..." арыентуе пісьменніка, акрамя вызначанага вышэй, і на працэс асэнсавання прычын і вынікаў неспакойнага стану душы творцы.

Такім чынам, у вершы В. Ластоўскага "Пішы..." назіраем цэлы комплекс літаратурна-эстэтычных парад, на якія гэты пісьменнік арыентуе сваіх паплечнікаў са сферы літаратурна-мастацкай творчасці: парад адносна зместу літаратуры, аб'ектаў і з'яў, што павінны адлюстройвацца, умой мастацкай творчасці.

Сэнс уласных творчых намаганняў В. Ластоўскі вызначыў у вершы “Форма ў трупелых я вораг дасконны..." (1923). Формаў трупельх я вораг дасконнь, // сцежак стаптаных не зношу тварэнні; // новым імкненням даць новыя формы, // новыя словы $і$ дум выражэння // стайлю я мэтай (209).

Гэты верш сведчыць пра наступную творчую ўстаноўку, мэту В. Ластойскага: наватарства ў літаратурнай творчасці; яно, паводле вызначэння Я. Янушкевіча, было мастачкім крэда $a^{22}$ паэта.

Эстэтычная праблематыка лірыкі В. Ластоўскага прадстаўлена яшчэ адной сферай: асабова-творчай, грамадска-рэцэпцыйнай; яна найбольш выразна акрэсліваецца і развіваецца ў такіх творах, як "Чала

22 Я. Янушкевіч, Вяртанне з нематы, [у:] В. Ластойскі, Выбраны творы, Мінск 1997, c. 24. 
я не хіліў прад сілай" (часопіс "Крывіч", 1924 [№ 1]), "У час аблогі", "Падарожнік" ("Крывіч", 1927 [ліпень-сакавік - № 12]) (472). Вобразы гэтых твораў, мастацка-фактуальны іх кантэкст, адпаведныя эпізоды жыцця і творчасці (1919-1927 гг.) В. Ластойскага дазваляюць меркаваць, што лірычны герой і асоба аўтара ў іх - постаці ройназначныя. У працэсе інтэрпрэтацыі мастацкіх вобразаў і ідэйнага зместу гэтых твораў мэтазгодна ўлічваць наступныя факты з жыцця і дзейнасці В. Ластоўскага перыяду 1924-1927 гг.

Дваццатага красавіка 1924 года В. Ластоўскі падаў у адстаўку з пасады прэм'ер-міністра. Працаваў у Міністэрстве беларускіх спрай у Літве, выдаваў часопіс «Крывіч» (1923-27), надрукаваў некалькі падручнікаў. (...) Запрошаны Інбелкультам на акадэм[ічную] канферэнцыю па рэформе бел[арускага] правапісу і азбукі (ліст[апад] 1926) (...) Пад націскам неспрыяльных абставін (літоўскі ўрад адмовіўся фінансаваць выданне «Крывіча» і Бел[арускі] цэнтр у Коўне, паліт[ычны] пераварот 17.12.1926 у Літве) у крас[авіку] 1927 пераехаў у БССР. (...)

Выдаў «Падручны расійска-крыўскі (беларускі) слойнік» (Коўна, 1924) (...) У 1925 апублікаваў «Летапісца Вялікага княства Літоўскага і Жамойцкага» паводле спісу Рачынскага. Аўтар «Гісторыі беларускай (крыўскай) кнігі» (1926) (...)"23.

“Чала я не хілі ў прад сілай". У фінале гэтага верша (два апошнія радкі) аўтар ускосна "мадэлюе" абставіны абвінавачвання лірычнага героя у яго грамадскіх і творчых грахах: Вось гэта ўсе мае грахі, // Вось гэта ўсё, у иьлм я вінньи!.. (226).

Доказы лірычнага героя, яго аб'ектыўнай невінаватасці, прадстаўлены $\ddot{y}$ сямі перадфінальных радках верша і прапанаваны $\ddot{y}$ форме чатырох вобразных тэзісаў-апраўданняў, эстэтычных сцверджанняў, якія адмаўляюць сацыяльнае і творчае прыстасавальніцтва. Вобразныя канстатацыі гэтай часткі твора акрэсліваюць эстэтычную пазіцыю В. Ластоўскага (калі прымем пад увагу тэзу пра эквівалентнасць вобраза лірычнага героя і асобы аўтара верша) у адносінах як да ўласнага грамадзянскай выбару, так і яго літаратурнай, навуковай дзейнасці.

Чала я не хіліў прад сілай. Сіла - большасць - не з'яўляецца для лірычнага героя ісцінай, крытэрыем справядлівасці; магутнасць гэтай ciлbl яшчэ не прычына для схілення яго галавы як знаку прымірэння, падпарадкавання ўсталяваным ёй правілам, прынцыпам і законам.

23 Я. Янушкевіч, Я. Ластоўскі Вачлаў Юстынавіч, [у:] Энцыклапедыл гісторыі Беларусі ў шасиі тамах, Мінск 1993-2000, т. 4, с. 336-337. 
Не качайся полазам у порсиі. Гэтым адмаўленнем сцвярджаецца імкненне лірычнага героя да незалежнасці ў сацыяльных зносінах і творчасці. Ён не быў прыладай брыдкіх мэт і іх здзяйснення у пыле грамадскага існавання. Параўнаем некаторыя з лексічных значэнняу слоў, пакладзеных у аснову прыведзенага вышэй метафарычнага выказвання лірычнага героя. Полаз (другое з лексічных значэнняў гэтага назойніка) - спецьляльны брус, які падкладаециа пад ніз прь перавозuь ияжару, пры спуску суднаў і інш. ${ }^{24}$ Порсць - пыл. В. Ластоўскі $\ddot{y}$ "Падручным расійска-крыўскім (беларускім) слоўніку" дае наступны пераклад назойніка пьлль з рускай на беларускую мову. Пьлль - nьлл (...), порсць, порсьнь (...)" 25 .

Клумлівай $i$ mупой тайпе не біў паклонаў я. Дадзенае адмаўленне сінанімічнае першаму з вылучаных вышэй; пры гэтым яно ўдакладняе яго. Ciлa, натойп (may̆na) у гэтым выпадку хлуслівая, тупая. Непахіснасць лірычнага героя адмаўляе публічную згоду з грамадскай хлуснёй і тупасцю, фальшам, прыстасаваннем, пры дапамозе якіх натойп (хаатычнае зборышча людзей, што супрацьпастаўляюць сябе незалежным, адметным асобам) імкнецца прадэманстраваць сваю згоду з ciлай, што пануе у у грамадстве, а таксама хлуслівае, прытворнае яднанне вакол гэтай ciльл.

Праторань дарожкі з пагардай абмінаў, // ламаючь шчьрэи навіны. Дадзенае сцверджанне адмаўляе лёгкі грамадскі, жыццёвы, творчы шлях, які не прымаў В. Ластойскі - прэм'ер-міністр БНР, паэт, гісторык, адвяргаючы шчырэи (шчыраванне) на ніве ўкаранення новай, новага часу “праўды”, якую ён адпрэчваў.

У якасці некаторых 3 падмацаванняў прыведзеным вышэй высновам прапануем наступныя факты: сцверджанні В. Ластойскага адносна радькальнай народнай праграмьл, скіраванай супраць польскага $і$ маскойскага засілля (ліст да Антона Луцкевіча (1916)), а таксама ацэнкі Я. Янушкевіча вынікай грамадска-палітычнай дзейнасці В. Ластойскага ў эміграцыі.

(...) у змаганні з польскім і маскоўскім засіллем у нашым краі ядыная дарога наша правільная - гэта радыкальная народная праграма. Ідучы гэтай дарогай, мы найхутчэй дойдзем да сваёй мэты, а гэта дзеля таго, што ў нас (...) каставае ўстройства, і апёршыся на адной касце, касце беларуска-мужыцкай, мы можам стварыць сілу. Ведама, прыйдзецца горкай

24 Тлумачальны слоўнік беларускай мовы.., т. 4, с. 288.

25 В. Ластойскі, Падручны расійска-крыйскі (беларускі) слойнік.., с. 579. 
шмат праўды пры гэтым сказаць, але тым лепей, тым скарэй прабудзіцца пачуццё сваёй каставай (каторая і без таго моцна ў народзе) асобнасці.

Усякая ж угодавая палітыка (...) вядзе Беларусь да ганебнага ўпадку. Каб работа развівалася, патрэбны фанатыкі святой справы, а не млявыя ўгодайцы, каторыя за вераб'я на страсе родную Бацькайшчыну гатовы прадаць «пяці нацыям» (432).

Знаходзячыся ў няпростых для палітычнай дзейнасці ўмовах, урад БНР на чале з Ластойскім тым не менш меў адчувальныя поспехі у знешняй палітыцы. У 1920-1923 гадах Вацлаў наведаў з дыпламатычнымі місіямі Бельгію, Германію, Ватыкан, Італію, Чэхаславакію, Францыю, Швейцарыю. На кожнай урачыстай аўдыенцыі, міжнароднай канферэнцыі, палітычнай нарадзе прэм'ер-міністр выступае як беларус, ад імя Беларусі і дзеля будучыні Беларусі. Кожны здзек з роднага народа - гэта здзек з яго самога, прэм'ера Ластоўскага ${ }^{26}$.

"У час аблогі". Гэты верш у прозе паводле зместу ўяўляе сабой споведзь лірычнага героя пра трагізм яго адзіноты як выніку, па-першае, неразумення паплечнікамі, па-другое, здрады з боку тых, для каго ён мацаваў свой горад. Аблога ў адносінах да лірычнага героя і яго горада (яны акружаны варожымі войскамі з мэтай іх захопу) гэта праява, з якой сутыкнуйся пісьменнік у той перыяд, калі стварайся гэты верш. Горад (лёс, літаратурная і навуковая спадчына), створаны В. Ластойскім, знаходзіўся ў аблозе і пасля вяртання пісьменніка з эміграцыі ў Беларусь, і на працягу дзесяцігоддзяў пасля расправы з ім таталітарнай сістэмы.

Дубовая сияна, байніщь, мост на зводах, усякае дабро ў клечях, верная дружына - усё гэта аказалася марнымі і ілюзорнымі намаганнямі лірычнага героя перад тварам і навалай ворага многага.

Асабліва трагічна гучаць тыя радкі твора, якія сцвярджаюць адзіноту лірычнага героя ва ўмовах аблогі яго горада.

Трагічны змест, закладзены ў творы, узмацняецца яшчэ і тым, што агучаныя ў ім сцверджанні сталі прарочымі ў адносінах да лёсу самога айтара. У час аблогі, разгорнутай супраць В. Ластойскага пасля яго вяртання ў Беларусь, спадчына (трывожны звон) пісьменніка, вучонага не была належным чынам запатрабавана ні ў перыяд, калі ён яшчэ жыў, ні ў наступныя (ажно да постсавецкага часу): В. Ластойскі заставаўся адзінокім у створаным ім горадзе нацыянальнай ідэі, грамадзянскай эстэтыкі: I от нахльннуц̆ вораг многі. // Ударыуу я у звон трьввожныл. // Дзинеў патужна ияжкі спіж... // Аднак на клік мой

26 Я. Янушкевіч, Вяртанне з нематы.., с. 12. 
зойны ніхто ка мне не паспяшыу : // У горадзе маім - такім иудойным - адзін я бый!.. (228).

"П а д ар ожнік". У гэтым вершы у прозе назіраем сукупнасць матываў, кожны з якіх вобразна рэпрэзентуецца ў адпаведнай яго частцы (у папярэдне прааналізаваным творы дамінуе адзін матыў: марнасці, ілюзорнасці збіральных намераў лірычнага героя).

Матывы дадзенага твора можна прадставіць наступным чынам.

Вандраванне і сацыяльнае раздарожжа (першая частка). Я клункі ўжо злажыу $і$, сукатаю кульбою падпёршыся, гляджу на раздарожbl (229).

Боль і пакута падарожніка (другая частка). Панукаю вісіиь штодзённы боль няўнімны (229).

Чаканне зыходу пакутніка-падарожніка з жыццёвай дарогі (трэцяя частка). Калі ж, калі канеи трудлівай будзе падарожы? (229).

Супастаўленне мастацкіх вобразаў гэтага твора і сэнсу, які яны ўтрымліваюць у сабе, з фактамі жыцця В. Ластоўскага прыводзіць да наступнай высновы. Прадчуванні пісьменніка перад яго прыездам у Мінск на мовазнаўчую канферэнцыю (1926) і канчатковым вяртаннем (1927) у Беларусь - гэта стан вандроўніка, які разумее, што "мытны дагляд" перад апошняй часткай яго падарожжа можа мець трагічны фінал: А ўкруг мяне стаяџь старожы, гатовыя вароты расчынічь, калі я мыта аплачу душы маёй аздобамі. (...) Магілішчь кругом... за кожнай брамаю капещ... (229).

Тым не меней, пісьменнік, як і яго лірычны герой, працягвае сваё падарожжа (падарожу), спадзеючыся на шчаслівае яго заканчэнне. Але гэтае спадзяванне мае адценне нейкай безвыходнасці. 3 ёю і сутыкнуўся пісьменнік у хуткім часе пасля публікацыі творай "У час аблогі" i "Падарожнік": ён адным з першых вярнуўся у Беларусь з эміграцыі і адным з першых быў знішчаны дазорнылі саиьляльнай справядлівасиі, ройнасиі і свабоды.

У ахарактарызаваных вышэй трох вершах В. Ластоўскага назіраем сцвярджэнне яго эстэтычнай пазіцыі як творцы і грамадзяніна ("Чала я не хіліў прад сілай"), а таксама трагічны яе вынік у праекцыі на функцыянаванне спадчыны пісьменніка ("У час аблогі"), на перспектыву канца трудлівай [цяжкай. - A. M.] падарожы: грамадскай і творчай ("Падарожнік").

Эстэтычная праблематыка, прадстаўленая у лірыцы В. Ластоўскага, адсылае чытача да трох сфер: грамадзянскай, творчай, асабовай. Цэнтральнымі паняццямі ў гэтых сферах з'яўляюцца наступныя: Радзіма, яе абаронцы і ворагі; ранейшае, цяперашняе і будучае 
жыццё Бацькаўшчыны і яе сыноў; шлях да вызвалення Айчыны; прадмет і спосабы яго адлюстравання у літаратурным творы; перадумовы стварэння пераканальных мастацкіх вобразай; грамадзянская пазіцыя творцы, яго адзінота, адрынутасць; узоры ідэйнага ўмацавання твоpa i інш.

\section{Л I T A P A T У P A}

Байкоў М., Некрашэвіч С., Беларуска-расійскі слойнік, Мінск 1926.

Коваль У., Народныл ўяўленні, павер'і і прыкметы: Даведнік па ўсходнеславянскай міфалогіi, Гомель 1995.

Ластоўскі В., Выбраныля творы, Мінск 1997.

Ластоўскі В., Падручны расійска-крыусскі (беларускі) слоўнік, Коўна 1924.

Лепешаў І., Фразеалагічны слойнік беларускай мовы: У 2 тамах, Мінск 1993, т. 1 ; т. 2.

Литературный энииклопедический словарь, под общ. ред. В. М. Кожевникова, П. А. Николаева, Москва 1987.

Прокулевич В., Слуикое восстание, "Неман" 1996, № 4.

Селіванаў П., Брэсикі мір 1918, [у:] Энцыклапедыя гісторыі Беларусі: У 6 т., Мінск 1994, т. 2.

Слуикі збройны иьън 1920 г. У дакумэнтах і ўспамінах, Ул. Ляхоўскі, Ул. Міхнюк, А. Гесь, Мінск 2006.

Стужынская Н., Dei minoris [Да 75-годдзя Слуикага збройнага чыну], "Літаратура і мастацтва" 1995, 24 ліст.

Тлумачальны слоўнік беларускай мовы ў пячі тамах, Мінск 1977-1981, т. 3; т. 4 ; т. 5 , кн. 1.

Янушкевіч Я., Я. Ластойскі Ваилаў Юстынавіч, [у:] Энцыиклапедыля гісторыі Беларусі ў шасиі тамах, Мінск 1993-2000, т. 4.

Янушкевіч Я., Вяртанне з нематы, [у:] В. Ластоўскі, Выбраны творы, Мінск 1997.

\section{S T R E S Z C Z E N I E}

\section{ESTETYCZNA PROBLEMATYKA TREŚCI OBYWATELSKICH, TWÓRCZYCH I OSOBISTYCH W LIRYCE W. ŁASTOWSKIEGO}

W artykule opisano środki wyrazu, problematykę i treści ideowe liryki Wacława Łastowskiego. Autor artykułu zwraca uwagę na specyfikę przedstawiania takich 
estetycznych zagadnień, jak ideał obywatela, treść utworu literackiego, stanowisko estetyczne poety, estetyczny wybór jednostki, itd. Udowadnia, że poetycka koncepcja poddanych analizie utworów Łastowskiego stanowi sumę poglądów i przekonań, które w każdym kolejnym utworze (zgodnie z porządkiem chronologicznym) są doprecyzowane i rozbudowane. Autor definiuje i opisuje składowe tej koncepcji, do których zalicza ojczyznę, jej obrońców i wrogów, przeszłość, teraźniejszość i przyszłość ojczyzny i jej synów, drogę do wolności, przedmiot i sposoby jego wyrażenia w utworze literackim.

Słowa kluczowe: liryka, treść utworu, koncepcje poetyckie, sfera obywatelska, twórcza, osobista, patriotyzm.

\author{
S U M M A R Y
}

\title{
AESTHETIC ASPECTS OF CIVIL CREATIVE PERSONAL CONTENT IN V. LASTOVSKY'S LYRIC POETRY
}

The article presents the analysis of the figurative and expressive means, subject matter and conceptual content of V. Lastovsky's lyric poetry where the author's view of the civic consciousness, creativity and personal sphere are rendered. Special attention is drawn to the reflection of such aesthetic issues as the national ideal of a citizen, content of literary work, the poet's aesthetic values, personal aesthetic choice, etc. The article proves that the poetic conception of the analyzed works is the manifestation of the opinions and beliefs which become more specific, more elaborated and extended in every subsequent works (their chronology is taken into consideration). The sense-shaping components of this conception are defined and described including motherland, its defenders and foes, past, present and future life of homeland and its sons, the way to the liberation of motherland, subject and its manifestation in literary work, prerequisites to construct convincing artistic images, the author's civic attitude, his solitude, rejection; patterns of figurative topical stability of a literary work etc.

Key words: lyric poetry, content of literary work, poetic concept, civil, creative, personal sphere, patriotism. 